\title{
EFFECT OF SECONDARY METABOLITES FROM THREE ENTOMOPATHOGENIC FUNGI ON THE COTTON LEAF WORM, SPODOPTERA LITTORALIS (BOISD.)
}

\author{
IBRAHIM, A. A., ${ }^{1}$ B.H. HAROUN, ${ }^{2}$ A. F. EL-FEKKY ${ }^{3}$ and \\ H. K. BEKHIET ${ }^{1}$
}

1. Plant Protection Research Institute, ARC, Dokki, Giza, Egypt.

2. Faculty of Science -Al-Azhar University (Boys) Cairo.

3. Faculty of Agriculture, Al-Azhar University, Cairo.

(Manuscript received 9 August 2011)

\begin{abstract}
Three entomopathogenic fungi isolates, i. e., Beauveria bassiana, Paecilomyces fumosoroseus and Metarhizium anisopliae were used as biological control agents against the Egyptain cotton leaf worm, Spodoptera littoralis (Boisd.), which represent the most severe destructive cotton pest in Egypt and many other countries.

The entomopathogenic fungi were inoculated YES medium, incubation period was carried out for 19 days at $\mathrm{pH} 5.4$ and 28 $30^{\circ} \mathrm{C}$. After incubation period, the mats of the fungi were removed and YES broth was mixed individually with chloroform/methanol $(2: 1, v / v)$. The mixture was shaken vigorously in a separating funnel and left to settle down forming a dense lower aqueous layer containing the secondary metabolites. Extracted metabolites were then concentrated by using a speed vacuum device (Maxi Dry Plus) to a volume of $1 \mathrm{ml}$.

Virulence of $B$. bassiana, M. anisopliae and P. fumosoroseus was investigated against $1^{\text {st }}$ instar larvae of the cotton leaf worm $S$. littoralis. Results obtained revealed that the three metabolites (toxins) were toxic to the $1^{\text {st }}$ instar larvae of $S$. littoralis. The most effective toxin was $M$. anisopliae $(84.92 \%)$ followed by $P$. fumosoroseus (66.32\%) and B. bassiana (62.65\%).

On the other hand, $\mathrm{LT}_{50}$ values in days for $M$. anisopliae were $8.5414,6.4808,4.7721,3.7211$, while for $P$. fumosoroseus they were $11.0488,7.7757,6.4998,5.1703$ and for $B$. bassiana they were $10.4380,8.3415,6.8299,5.6922$ in relation to the concentrations $25,50,75,100 \%$ respectively.

Treatment of $S$. littoralis $4^{\text {th }}$ instars with $\mathrm{LC}_{50}$ of the metabolic fungal toxins caused complete disruption of endocuticle of the resulting late $6^{\text {th }}$ instars. Meanwhile, it caused exfoliation of the mid gut epithelium from the underlying circular muscle fibers, leaving a large vacuole or space, disruption of both the peritrophic membrane and columnar cells, beside high vacuolization and collapsing of the fat body.
\end{abstract}

\section{INTRODUCTION}

Cotton crop is one of the major sources for the economy in A.R.E. and other countries. The Egyptian cotton leaf worm Spodoptera littoralis (Boisduval) is one of the most important pests in Egypt, eastern Mediterranean region and other countries 
in Africa and Asia. Several plant hosts specially the cotton crop were attacked by the cotton leaf worm, during the growing season and causes great damage to a wide variety of crops including vegetables and fruit trees.

Until present, the hand picking of egg-masses is used as first step in the cotton leaf worm control, supplemented by the use of chemical insecticides. The problems followed the use of insecticides in control pest derived the attention to find alternative safe methods for cotton leaf worm control.

Insecticide resistance and the demand for reduced chemical inputs in agriculture led to the development of alternative forms of pest control. Biological means offer an attractive or supplement to the use of chemical pesticides. Microbial biocontrol agents are naturally occurring organisms and perceived as being less damaging to their environment. Furthermore, their generally complex mode of action makes it unlikely that resistance could be developed to bio-pesticides. The use of microorganisms as selective pesticides has had some notable successes. Great efforts have been made to control this pest chemically. Due to the continuous use of chemical pesticides against this pest, resistance to the action of pesticides had dramatically evolved. Also, the extensive use of these chemicals has given rise to problems such as residual toxicity (pollution) and harmful efforts on beneficial insects, which are natural enemies of target or non-target pest species. Such problems have become a cause of search for more safe pesticides including microbial agent as fungi, bacteria and viruses (Rashed 1993).

Generally, the death of on insect results from a combination of factors such as mechanical damage which resulting from tissue invasion, depletion of nutrient resources and toxicosis. Other factors, which may have a role in the demise of the insect hosts, are a range of low molecular weight insecticidal toxins produced by entomopathogenic fungi, e. $g$., Beauvericin, Beauverolides, Bassianolide and Isarolides which are produced by Beauveria bssiana (Elsworth 1977) as well as Destruxins and Cytochalasins produced by Metarhizium anisopliae.

\section{MATERIALS AND METHODS}

\section{Extraction of secondary metabolites:}

The fungi were inoculated to YES medium, incubation was carried out for 19 days at $\mathrm{pH} 5.4$ and incubated at $28-30^{\circ} \mathrm{C}$. After incubation, the mats were removed and YES broth was mixed individually with chloroform/methanol $(2: 1 \mathrm{v} / \mathrm{v})$. The mixture was shaken vigorously and left to settle down forming a dense lower aqueous layer 
containing the secondary metabolites. Extracted metabolites were then concentrated using a speed vacuum device (Maxi Dry Plus) to $1 \mathrm{ml}$.

\section{Toxin production medium}

Yeast Extract Sucrose liquid medium g/l:Sucrose, 150 and yeast extract , 20.

\section{Test insect}

The larvae were maintained on the semi-synthetic diet as described by (Mabrouk, et al., 1996).

\section{Toxocological studies}

S. littoralis larvae were obtained from the laboratory culture at Plant Protection Research Institute. Newly hatched larvae from a single egg batch were introduced to pots containing $0.5 \mathrm{~cm}$ thick the synthetic diet using a soft hairbrush, then transferred to plastic "poly pots" with dimensions of $5 \mathrm{~cm}$ deep and $10 \mathrm{~cm}$ internal diameter. Ten larvae were reared in each plastic cup until reaching pupae. Freshly emerged moths were coupled in small glass jars provided with a filter paper as a site for egg- laying, and supplied with $10 \%$ sugar or honey solution soaked in a peace of cotton wool. All experiments were carried out under constant conditions of $26 \pm 2^{\circ} \mathrm{C}$ and $60 \pm 5 \mathrm{RH}$.

\section{Virulence of isolated entomopathogenic fungi:}

Newly hatched larvae from a single egg batch was introduced to pots containing treated synthetic diet, three compounds were used. Four concentrations of each compound were prepared $100 \%, 75 \%, 50 \%$ \& 25\%. 500 ųl from each dilution were added to $5 \mathrm{gm}$ of diet. The larvae were left to feed on treated diet for $48 \mathrm{hrs}$, and then mortality percentages were recorded. The survived larvae were transferred to feed on untreated diet. Mortality percentages were corrected using Abbott's formula (Abbott 1925). The $L_{c 50}$ and $L_{c 90}$ values were calculated according to method of (Finney 1971).

\section{Histopathological effects of the fungal toxins on integument, fat body and midgut:}

The concentration of $\mathrm{LC}_{50}$ of $M$. anisopliae toxins was applied in the treatment. The influences of the entomopathogenic fungus $M$. anisopliae on the integument, fat bodies as well as mid-gut were studied.

After feeding the $4^{\text {th }}$ instar larvae on treated diet for $48 \mathrm{hrs}$, they were transferred onto untreated diet. The survived larvae were collected after 96 hrs.

In each treatment, five larvae were selected and starved for $4 \mathrm{hrs}$. to insure that the mid-gut is as empty as possible, then dissected by using the binocular microscope in Ringer's saline solution $(0.0065 \%)$. The mid-gut, chitin and fat bodies were removed and fixed in alcoholic Bouin's fluid for 24 hrs., washed several times in 70\% ethyl alcohol to remove most of the fixative and then dehydration takes place through 
ascending series of ethyl alcohol, 70, 80, 90, and $95 \%$ followed by two changes of absolute ethyl alcohol (30 min. for each) then transferred to a mixture of absolute ethyl alcohol and xylene and then to xylene (30 min. for each). After that, infiltration with wax took place by transferring to xylene-paraffin mixture for $30 \mathrm{~min}$. and then to three successive paraffin baths (30 min. for each) at $58^{\circ}-60^{\circ} \mathrm{C}$, then embedded in pure paraffin. Sectioning was done by a Rotary microtome at thickness of 5 ц. Paraffin ribbons were affixed on clean glass microscopal slides and flattened on hot plate for a period of $15 \mathrm{~min}$., then stained by using double stain, i.e., haematoxylin for nucleus and eosin for cytoplasm and cell wall. The staining procedure took place as follow: dewaxation carried out by passing the slides through xylene $I$, xylene $\Pi$ and then to a mixture of xylene and absolute ethyl alcohol ( $5 \mathrm{~min}$. for each) and then hydrate to water by running through descending series $(100,95,90,80,70,50$, and $30 \%)$ of ethyl alcohol and then to distilled water ( $2 \mathrm{~min}$. for each). Sections were stained in haematoxylin for $5 \mathrm{~min}$. and rinsed in distilled water. Destained in $70 \%$ acid alcohol until light pink colour of specimen appeared and then neutralized in tap water, stained with eosin (15 sec.) and washed in 2 changes of 95\% ethyl alcohol then in absolute ethyl alcohol ( 5 min. for each). Clearing occured in 2 changes of xylene (5 min. for each), and then mounted with Canda balsam, covered with clean glass covers and left to dry in an electric oven at $37^{\circ} \mathrm{C}$. To evaluate the histopathological effects on the adult stage, virgin adults that resulted from treated newly hatched larvae were also dissected in Ringer's saline solution to examine testis and ovaries. Testis undergo the same previous technique, however, as for ovaries, they differ in certain steps in which, after fixation and dehydration, they transferred from $95 \%$ ethyl alcohol to methyl benzoate for clearing until it settled in the bottles bottom, washed with benzene for 5 min., then transferred to benzene and wax mixture and then running to three bathes of paraffin wax (30 min. for each), and then followed the routine technique previously described for larvae.

\section{RESULTS AND DISCUSSION}

\section{Virulence of isolated entomopathogenic fungi.}

Virulence of the fungal species under study was investigated against $1^{\text {st }}$ instars larvae of cotton leaf worm S. littoralis as shown in Tables 1, 2, 3 and figures 1,2,3. Results obtained revealed that the three tested metabolites were toxic to the $1^{\text {st }}$ instars larvae of S. littoralis. The most effective was that of M. anisopliae followed by B. bassiana and $\mathrm{P}$. fumosoroseus. The mortality percentages after 8 days were 39.46, 48.51, $55.44 \& 62.65 \%$ for the concentrations $25,50,75,100 \%$ of B. bassiana, $47.36,58.58$, 
$73.04 \& 84.92 \%$ for the same concentrations of M. anisopliae and $38.26,51.25,58.94$ \& $66.32 \%$ for P. fumosoroseus. Data in tables $4,5,6$ represents $L T_{50}$ values in days for B. bassiana to concentrations $25,50,75,100 \%$.

Table 1. Corrected cumulative mortality percentages of $1^{\text {st }}$ instars larvae of Spodoptera littoralis after feeding on synthetic diet treated with metabolic toxins of Beauveria bassiana.

\begin{tabular}{|c|c|c|c|c|}
\hline \multirow{2}{*}{ Conc. (\%) } & \multicolumn{4}{|c|}{ Cumulative mortality \% at indicated days after treatment } \\
\cline { 2 - 5 } & 2 & 4 & 6 & 8 \\
\hline 25 & 4.84 & 16.76 & 28.90 & 39.46 \\
\hline 50 & 10.05 & 25.52 & 38.40 & 48.51 \\
\hline 75 & 14.39 & 32.17 & 45.54 & 55.44 \\
\hline 100 & 16.08 & 36.91 & 51.99 & 62.65 \\
\hline
\end{tabular}

Table 2. Corrected cumulative mortality percentages of $1^{\text {st }}$ instar larvae of Spodoptera littoralis after feeding on synthetic diet treated with metabolic toxins of Metarhizium anisopliae.

\begin{tabular}{|c|c|c|c|c|}
\hline \multirow{2}{*}{ Conc. (\%) } & \multicolumn{5}{|c|}{ Cumulative mortality \% of indicated days after treatment } \\
\cline { 2 - 5 } & 2 & 4 & 6 & 8 \\
\hline 25 & 7.08 & 22.12 & 36.03 & 47.36 \\
\hline 50 & 11.32 & 30.98 & 46.84 & 58.58 \\
\hline 75 & 15.07 & 41.69 & 60.72 & 73.04 \\
\hline 100 & 20.38 & 54.08 & 74.11 & 84.92 \\
\hline
\end{tabular}

Table 3. Corrected cumulative mortality percentages of $1^{\text {st }}$ instars larvae of Spodoptera littoralis after feeding on synthetic diet treated with metabolic toxins of Paecilomyces fumosoroseus.

\begin{tabular}{|c|c|c|c|c|}
\hline \multirow{2}{*}{ Conc. (\%) } & \multicolumn{4}{|c|}{ Cumulative mortality \% of indicated davs after treatment } \\
\cline { 2 - 5 } & 2 & 4 & 6 & 8 \\
\hline 25 & 5.69 & 17.36 & 28.61 & 38.26 \\
\hline 50 & 6.77 & 23.24 & 38.78 & 51.25 \\
\hline 75 & 9.97 & 29.85 & 46.53 & 58.94 \\
\hline 100 & 17.97 & 40.22 & 55.71 & 66.32 \\
\hline
\end{tabular}


Table 4. $\mathrm{LT}_{50}$ fucidal limits and slope values of $1^{\text {st }}$ instars larvae of Spodoptera littoralis after feeding on treated synthetic diet with metabolic toxins of Beauveria bassiana.

\begin{tabular}{|c|l|c|c|c|c|}
\hline \multirow{2}{*}{ Conc } & \multirow{2}{*}{$\begin{array}{l}\text { LT } \\
\text { (days) }\end{array}$} & \multicolumn{2}{|c|}{$95 \%$ Fucidal limits } & \multirow{2}{*}{ A Intercept } & $\begin{array}{c}\text { b } \\
\text { Slope }\end{array}$ \\
\cline { 3 - 4 } & Lower & Upper & & In \\
\hline 25 & 10.4380 & 7.7256 & 23.1728 & $2.6435 \pm 0.4538$ & $2.3135 \pm 0.6086$ \\
\hline 50 & 8.3415 & 6.3753 & 15.5157 & $3.1005 \pm 0.3819$ & $2.619 \pm 0.5277$ \\
\hline 75 & 6.8299 & 5.3521 & 10.9044 & $3.3370 \pm 0.3539$ & $1.9930 \pm 0.4973$ \\
\hline 100 & 5.6922 & 4.5871 & 7.7397 & $3.3519 \pm 0.3466$ & $2.1821 \pm 0.4911$ \\
\hline
\end{tabular}

Table 5. LT 50 fucidal limits and slope values of $1^{\text {st }}$ instar larvae of Spodoptera littoralis after feeding on treated synthetic diet with metabolic toxins of Metarhizium anisopliae

\begin{tabular}{|c|c|c|c|c|c|}
\hline \multirow{2}{*}{$\begin{array}{l}\text { Conc. } \\
(\%)\end{array}$} & \multirow{2}{*}{$\mathrm{LT}_{50}$ (days) } & \multicolumn{2}{|c|}{ 95\% Fucidal limits } & \multirow{2}{*}{$\begin{array}{c}\text { A } \\
\text { Intercept }\end{array}$} & \multirow{2}{*}{$\begin{array}{c}\text { b } \\
\text { Slope }\end{array}$} \\
\hline & & Lower & Upper & & \\
\hline 25 & 8.5414 & 6.6590 & 14.7417 & $2.8284 \pm 0.4128$ & $2.3312 \pm 0.5621$ \\
\hline 50 & 6.4808 & 5.2842 & 8.4186 & $3.0775 \pm 0.2732$ & $2.3687 \pm 0.3659$ \\
\hline 75 & 4.7721 & 3.9702 & 5.7777 & $3.1427 \pm 0.3530$ & $2.7365 \pm 0.5040$ \\
\hline 100 & 3.7211 & 3.1065 & 4.3460 & $3.2413 \pm 0.2530$ & $3.0912 \pm 0.3577$ \\
\hline
\end{tabular}

Table 6. $\mathrm{LT}_{50}$ fucidal limits and slope values of $1^{\text {st }}$ instar larvae of Spodoptera littoralis after feeding on treated synthetic diet with metabolic toxins of Paecilomyces fumosoroseus

\begin{tabular}{|c|c|c|c|c|c|}
\hline \multirow{2}{*}{$\begin{array}{c}\text { Conc } \\
\text { (\%) }\end{array}$} & \multirow{2}{*}{$\mathrm{LT}_{50}$ (days) } & \multicolumn{2}{|c|}{$95 \%$ Fiducial limits } & \multirow{2}{*}{$\begin{array}{c}\text { A } \\
\text { Intercept }\end{array}$} & $\begin{array}{c}\text { B } \\
\text { Slope }\end{array}$ \\
\hline 25 & 11.0488 & 7.9041 & 29.1485 & 2.7774 & $2.1303 \pm 0.5909$ \\
\hline 50 & 7.7757 & 6.2653 & 11.7734 & 2.7441 & $2.5326 \pm 0.5660$ \\
\hline 75 & 6.4998 & 5.3439 & 8.8618 & 2.9619 & $2.5072 \pm 0.5288$ \\
\hline 100 & 5.1703 & 4.1655 & 6.7334 & 3.4148 & $2.2217 \pm 0.4854$ \\
\hline
\end{tabular}


Table 7. Values of $\mathrm{LC}_{25}, \mathrm{LC}_{50}$ of metabolic toxins against $1^{\text {st }}$ instar larvae of Spodoptera littoralis ( Boisd )

\begin{tabular}{|l|c|c|}
\hline Fungi (Pathogens) & $\mathrm{LC}_{25} \quad$ values & $\mathrm{LC} \mathrm{C}_{50}$ values (\%) \\
\hline Metarhizium anisoplae & 11.631 & 27.538 \\
\hline Beauveria bassiana & 11.867 & 53.478 \\
\hline Paecilomyces fumosoroseus & 15.759 & 48.448 \\
\hline
\end{tabular}

Data in table 7 showed lethal concentrations required to kill $25 \%$ and $50 \%$ of treated larvae of $S$. littoralis, where LC25 was $11.631 \%, 11.867 \%$ and $15.759 \%$ for $M$. anisopliae, B. bassiana \& P. fumosoroseus, respectively. $L_{50}$ recorded $27.538 \%$ for M. anisopliae, 53.478 for B. bassiana and $48.448 \%$ for $P$. fumosoroseus. All tested isolates were found to be virulent to the test insect. The obtained results showed that M. anisopliae was the most effective isolate (84.92 \%) then $P$. fumosoroseus (66.32 $\%)$ and B. bassiana (62.65\%) after 8 days. Present data reveal differences in virulence among the 3-entomopathogenic fungi isolates. This isolates specific differences in virulence exemplified the interspecific variation exists in entomopathogenic fungi even when insect hosts were the same bioassay species. This is agree with (Hsieh et al., 1998) as they found that the extract of fermentation broth of M. anisopliae var. anisopliae showed high virulence to $S$. exigua as $86.7 \%$ mortality of 3rd instars larvae after 24 hours of infection and $95 \%$ mortality after 2 days.

(St. Leger 1995) mentioned that there are several broad classes of pathogenicity genes. Other pathogenicity genes may encode enzymes that allow the fungus to overcome their host barriers. Therefore extensive genetic variation in pathogenicity waits characterization at the molecular level

\section{Histological studies}

The integument of normal $6^{\text {th }}$ instars of $S$. littoralis consists of cuticle, hypodermis and basement membrane. Fig. (1), the cuticle is divided into three layers, the epicuticle followed by the exocuticle and endocuticle. The hypodermis consists of a single layer of less cuboidal or columnar cells. Each cell contains a large nucleus. The basement membrane is attached to the basal surface of the hypodermal cells. Treatment of $4^{\text {th }}$ instars with $\mathrm{LC}_{50}$ of the metabolic fungal toxins completely disrupt the formation of endocuticle of the resulting late $6^{\text {th }}$ instars. Fig. (2). 


\section{Mid gut}

It is composed of two layers of muscle fibers. Next to the inner layer inwards is a basement membrane, followed by an epithelial layers of cells lining the mid gut cavity within the lumen, there is a thin peritrophic membrane. Fig. (3).

Microscopic examination revealed that treatment of $4^{\text {th }}$ instars with $\mathrm{LC}_{50}$ of the metabolic fungal toxins caused exfoliation of the mid gut epithelium from the underlying circular muscle fibers, leaving a large vacuole, disruption of both the peritrophic membrane and columnar cells. Fig (4).

\section{Fat body}

The fat body of normal $6^{\text {th }}$ instars of $S$. littoralis in section is ribbon-like. The fat body cells are closely adherent and a delicate membranous sheath covers the external surface of the cell masses. Fig. (5).Treatment of $4^{\text {th }}$ instars caused high vacuolization and collapsing of the fat body. Fig. (6).

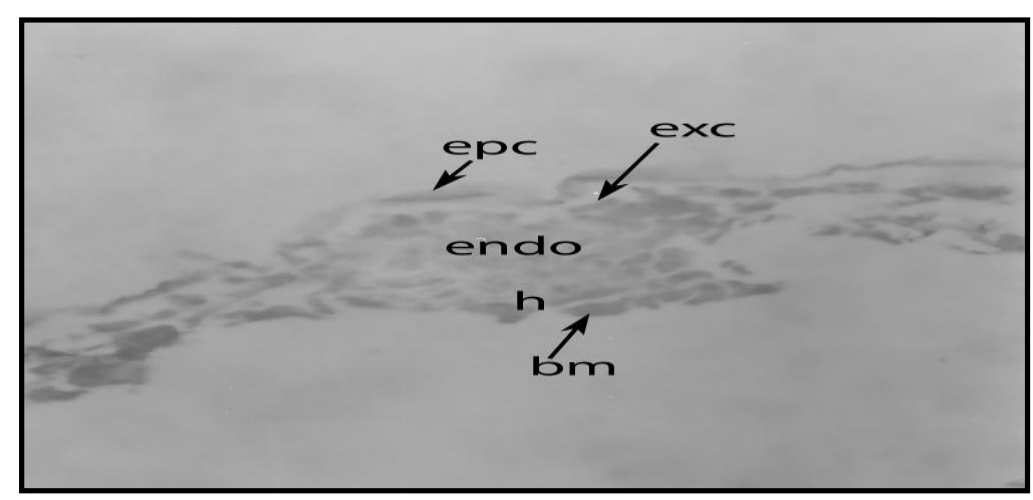

Fig. 1. Photomicrograph of L.S. in the integument of normal late $6^{\text {th }}$ larval instar of Spodoptera littoralis where $\mathrm{Bm}=$ Basement membrane, end. $=$ endocuticle , Epc. $=$ Epicuticle , Exc. $=$ exocuticle, $\mathrm{h} .=$ Hypodermis

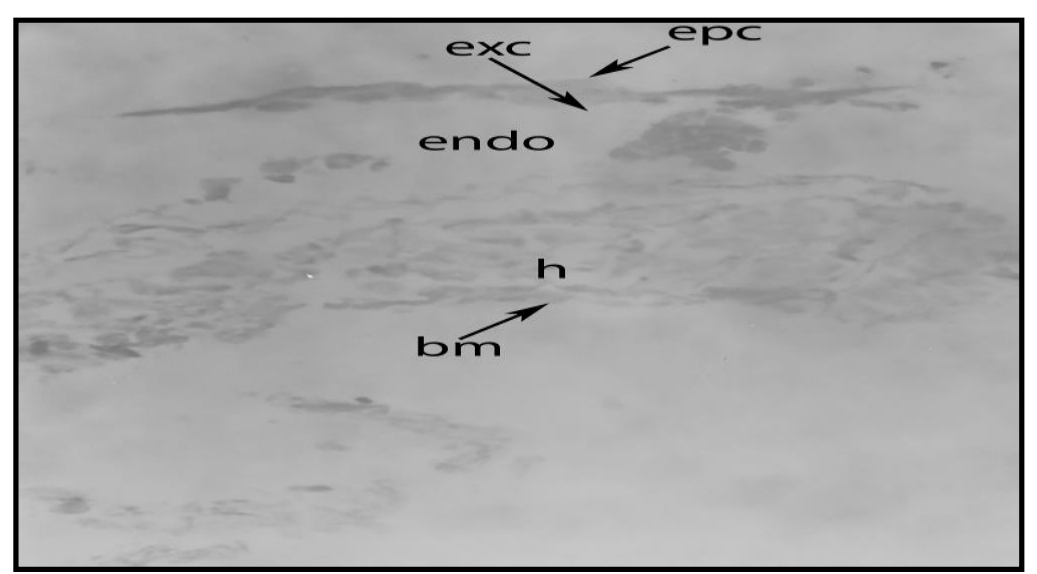

Fig. 2. Photomicrograph of LS. in the integument of late 6th larval instar of $\mathrm{S}$ littoralis after feeding on synthetic diet treated with LC50 of metabolic toxins of Metarhizium anisopliae. 
Fig. 3. Photфmicrograph of T.S. in midgut of normal late $6^{\text {th }}$ larval ins ars of Spodoptera littoralis where $\mathrm{Cc}=$ columnar cell, $\mathrm{clm}=$ circular huscle layer , Ge=globlet cell ,Iml=longitudinal muscle layer $\mathrm{Pm}=$ Peritrophic membrane, re=regenerative cell , Sh.=striated border , v.= vacuole

Fig. 4. Photomicrograph of T.s. in the midgut of late $6^{\text {th }}$ larval instar of 5 iltioralis alter feeding on synthetic alet treated with $\mathrm{LC}_{50}$ of metabolic toxins of Metarhizium anisopliae.

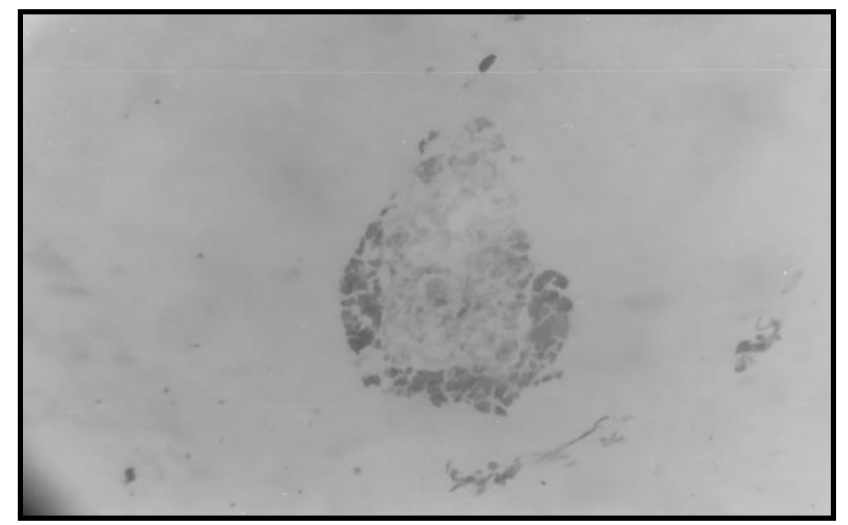

Fig. 5. Photomicrograph of L.s. in the fat body of normal late $6^{\text {th }}$ larval instar of $S$ littoralis. 


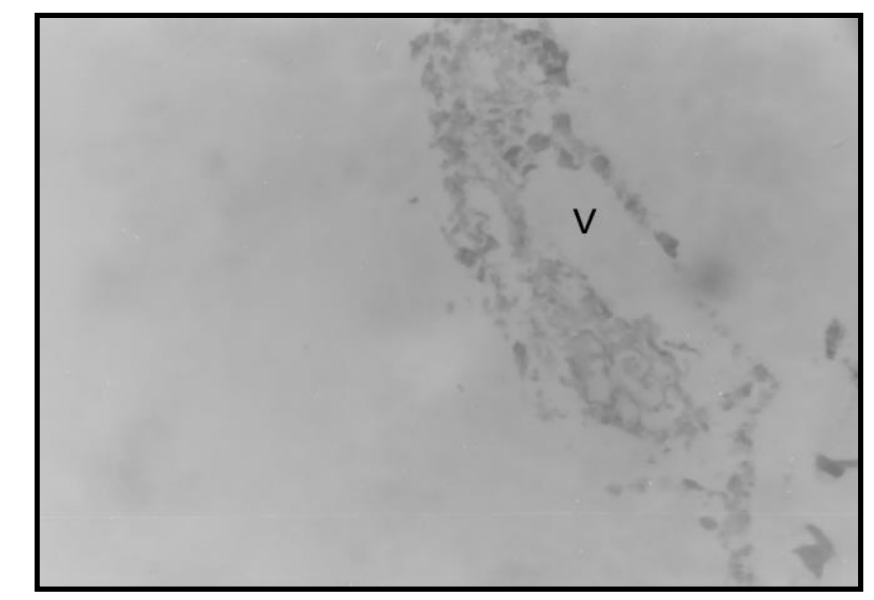

Fig. 6. Photomicrograph of L.s. in the fat body of late $6^{\text {th }}$ larval instar of $S$ littoralis after feeding on synthetic diet treated with $\mathrm{LC}_{50}$ of metabolic toxins of Metarhizium anisopliae. v: vacuole

Histopathological changes due to the effect of various toxicants have been a subject of considerable discussion among authors as the primary cause of insect's inactivity and consequent death. Many of the histopathological changes of the cuticle observed in the present study for $S$. littoralis late 6 th instars due to treatment of 4 th instar ones with entompathogenic fungal toxins. The obtained results agreed with (Hegazy, 1990) when using different chitin synthesis inhibitors against the same insect species. (Philogene and McFarlane 1967) established quite thoroughly the evidence necessary to conclude that the process of chitin synthesis is extracellular. They reported that cuticle precursor forms layers on the surface or very close to the surface of secretory cells, and that cuticular deposition may be completed at a distance from the secretory sites. They also linked oenocytoids and their secretions with cuticle formation in vivo. Moreover, (Essawy et. al., 1985) observed phenoloxidase activity in this type of cells.

The collapsing, lysis and vacuolization of the fat body of $S$. littoralis late 6th instars appeared in treatment with entomopathogenic fungal toxins. Results obtained with 4th instars agree with those of (Wang and Zhang 1987) for the fat body of Pieris rape larvae treated with an unspecified chitin synthesis inhibitor (designated as No. 3), and by (Meola et al., 1996) for the fat body of Ctenocephalidis felis adults treated with pyriproxyfen. (Munson 1954) reported that fat body of insect plays an important role in the storage of insecticides.

Many of the histopathological alterations reported in the present study for the midgut of $S$. littoralis late $6^{\text {th }}$ instars treated with the three entomopathogenic fungi as 4th instars agree with those reported by other authors. (AboEl-Ghar et. al., 1994) reported that $0.01 \mathrm{ppm}$ of diflubenzuron caused vacuolization of the midgut epithelium of $S$. littoralis larvae, in addition to the 
sloughing off of scattered groups of the midgut epithelium into the gut lumen and disappearance of the cell boundaries. Similar observations were also recorded for the midgut epithelium of the chironomid larvae, Chironomus decorus and Tapnypus grodhausi, when each was treated with both of diflubenzuron and triflumuron (Pelsue 1985), the cat flea adult, Ctenocephalidis felis (Meola et al., 1996) and of Aedes aegypti larvae (Syafruddin et al., 1990), that were treated with pyriproxyfen.

( Federici 1993) found that the ingestion of toxicant by the insects release a toxic peptide, which binds to sites on the microvilli membranes of the midgut causing cytolysis. This latter process leads to paralysis and subsequently death of the insect. All toxicants are not equally lipophilic and many are polar compounds. In general, polar compounds are not freely permeable to cell membrane. Polar nature of toxicants may possibly denature cellular proteins. The coagulated fibrous and reticular type of cytoplasm, particularly in case of treatment with entomopathogenic fungal toxins, may account for the denaturation of the cellular proteins. Fungal toxins may have calciumbinding properties and may disorganize the cementing substance between cells and tissues, resulting in exfoliation of epithelium from underlying muscularies. Lipophilic properties of fungal toxins will obviously affect the lipid layers of the membrane, which may ultimately destroy specific permeability properties of plasma membrane. This may lead to water loss causing dehydration and possibly vacuolization. Shrinkage due to dehydration may lead to the collapse of the lumen of midgut epithelium and to the appearance of gaps among the adjacent microvilli. Exudation of cytoplasmic particles may be an attempt by the cells to eliminate toxic metabolic intermediates produced by the poisoning action of the fungal toxins. Nuclear pycnosis and disorganization of the nuclear material may be produced by the denaturation of the nuclear protein particularly shistones and DNA molecules.

\section{REFERENCES}

1. Abbott, W.S. 1925. A method of computing the effectiveness of an insecticides. J. Econ. Entomol., 18: 265-267.

2. Abo El-Ghar, G. E. S., H. S. A. Radwan, Z. A. El-Bermay and L. T. M. Zidan. 1994. Histopathological effects of abamectin, thuringiensin and diflubenzuron on the midgut of Spodoptera littoralis (Lepidoptera : Noctuidae) larvae. Bull. ent. Soc. Egypt, Econ.Ser., 21: 41-52.

3. Els Worth, J.F. and J.F. Grove. 1977. "Cyclodepsipeptides from Beauveria bassiana Bals. Part 1 Beauverolides H and I." J. Chem. Soc. (Perkin 1) 3: 270-284.

4. Essawy,M.M., A. Maleville and M. Brehelin. 1985. The haemocytes of Heliothis armigera: ultrastructure, functions and evaluation in the course of larval development. J. Morph., 186: 255-264. 
5. Federici, B.A. 1993. Insecticidal bacterial proteins identify the midgut epithelium as a source of novel target sites for insect control. Arch. Insect Biochem. Physiol., 22: 357371.

6. Finney, D.J. 1971. Probit Analysis. $3^{\text {rd }}$ Ed., Cambridge univ. Press, London.

7. Hegazy, G. 1990. Comparative study of certain benzoylphenyl ureas on the integument ultrastructure of the first instar larvae of Spodoptera littoralis (Boisd.). Ann. Agric. Sci., Special Issue, 521-529.

8. Hsieh,C. M., S. J. Tuan, S. C. Wang, S. S. Kao and Y. M. Tzeng. 1998. The virulence of destruxins from Metarhizium anisopliae var. anisopliae to Spodoptera exigua. J.Chin.Agricul. Chemic. Soci., 36 (6): 622-629.

9. Mabrouk, A.M., H.K.M. Bekheit and G.M. Moawad. 1996. Improvement of Spodoptera littoralis mass rearing technique for production of NPV. Egypt. J. Biol. Pest Control. 6 (2): 200-205.

10. Meola, R., S. Pullen and S. Meloa. 1996. Toxicity and histopathology of the growth regulators pyriproxylen to adults and eggs of the cat flea (Siphonapteras: Pulicidae). J. Med. Entomol., 33: 670-679.

11. Munson, S.C. 1954. Insect lipids and insecticide action. J. Econ. Entomol., 47: 578587.

12. Pelsue, F. M. 1985. Histopathological effects of two insect chitin inhibitors in the alimentary canal of chironomid midguts (Diptera :Chironomidae). Bull. Soc. Vect. Ecol., 10 (2):

72-89.

13. Philogene, B.J.R. and J.E. McFarlane. 1967. The formation of cuticle in the house cricket, Acheta Domestica L. and the role of Oenocytes. Can. J. Zool., 45: 181-190.

14. Rashed, E. 1993. In the bioinsecticide Bacillus thuringiensis and its applications in developing countries Eds. Salama, S., Morris, O.N. and E. Rashed Proceedings of an International Worlshop organized by NRC-Cairo, Agriculture Canada and IDRC, 4-6 November., 399: (1991).

15. St. Leger, R. 1995. The role of cuticle-degrading protease in fungal pathogenic of insects. Can. J. Bot., 73 (Suppl. 1): S1125-S1135.

16. Syafruddin, A., R. Arakawa, K. Kamimura and F. Kawamoto. 1990. Histopathological effects of an insect growth regulators, 4-phenoxyphenyl (RS)-2(2-pyridyloxy) pyridyloxy) propyl ether (pyriproxyfen), on the larval of Aedes aegypti.J. Sanit. Zool., 41 (1): $15-22$.

17. Wang, F. K. and Q. Y. Zhang. 1987. Histopathological changes of Pieris rapae L. treated with insect chitin synthesis inhibitor. No. 3. Chin. J. Biol. Cont., 3: 133-135. 
تأثثر بعض المنتجات الثانوية الأيضية لثلاثة فطريات ممرضة للحشرات علي دودة ورق القطن

$$
\begin{aligned}
& \text { أحمد علدى ابراهيم1 ، بكرى محمد هارون2 }
\end{aligned}
$$

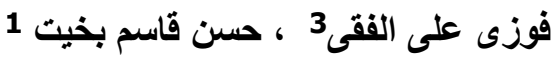

$$
\begin{aligned}
& \text { 1. معهر بحوث وقاية النباتات ـ مركز البحوث الزراعية- الدقى - جيزه - مصر } \\
& \text { 2. كلية العلوم جامعة الأزهر(بنبن) القاهرة } \\
& \text { 3. كلبة الزراعة جامعة الأزهر- القاهرة }
\end{aligned}
$$

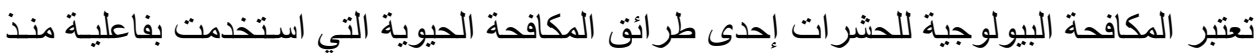

زمن طويل وتعتبر الآن في دائرة الاهتمام في ضوء حتمية التقليل من تلوث البيئة.

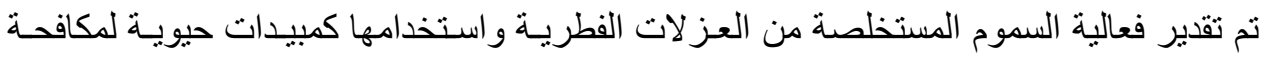

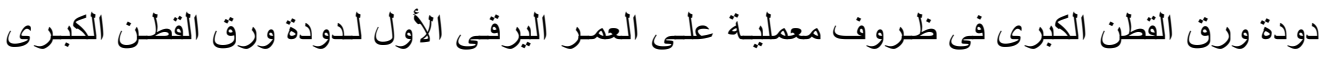

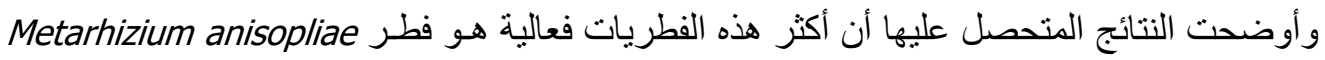
مسجلاً نسبة موت (84.92\%) بينما كانت نسبة الموت لفطر (66.32\%) وكانت نسبة الموت لفطر (82\%) هـ (62.65\%).

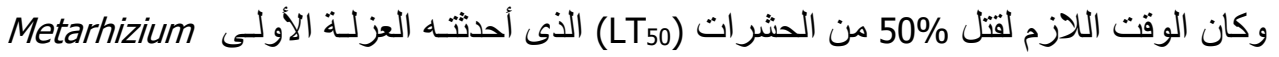

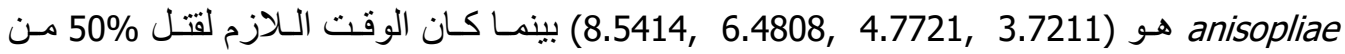

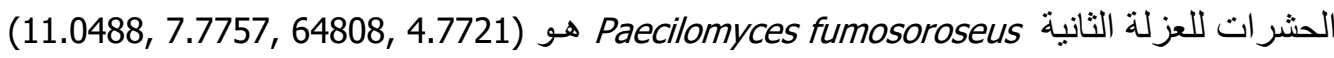

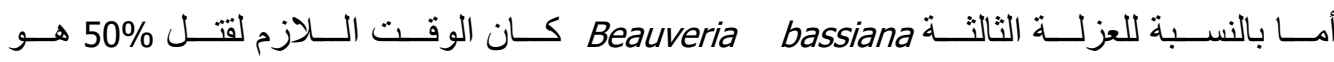

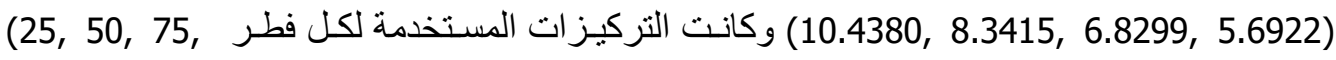
$.100 \%)$

أحدثت معاملة الطور اليرقى الر ابع لدودة ورق القطن بالمنتجات الأيضية لفطر الـ Metarhizium

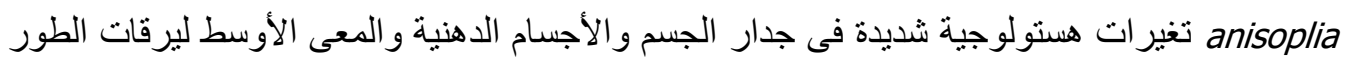

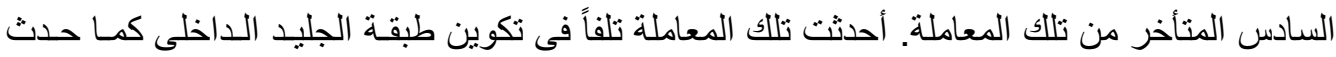

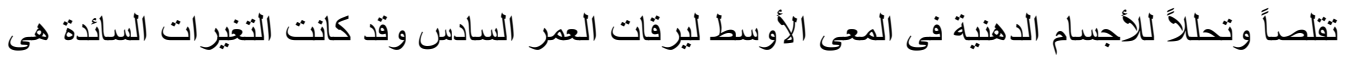
تكوين فجوات فى الخلايا الطلائية مع إحداث تلف في الأئ الغثاء المحيط بالغذاء.

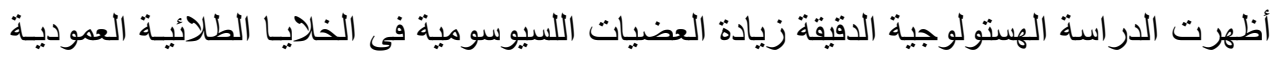
للمعى الأوسط مع أحداث تلف فى الخملات الدقيقة وتكوين فجوات فى سيتوبلازم الخلايا العمودية. 